\title{
The physical attributes of the Lake Naivasha catchment rivers
}

\author{
Mark Everard ${ }^{1, *}$, Jacqueline A. Vale ${ }^{2}$, David M. Harper ${ }^{3}$ \& Håkan Tarras-Wahlberg ${ }^{4}$ \\ ${ }^{1}$ The Natural Step U.K., 9 Imperial Square, Cheltenham, Gloucestershire GL50 1QB, U.K. \\ ${ }^{2}$ Environment Agency, Rio House, Waterside Drive, Aztec West, Almondsbury, Bristol BS32 4UD, U.K. \\ ${ }^{3}$ Department of Biology, Leicester University, Leicester LE1 7RH, U.K. \\ ${ }^{4}$ Swedish Geological AB, Box 19090, 10432 Stockholm, Sweden \\ *Present address: Environment Agency, King's Meadow House, King's Meadow Road, Reading, Berkshire RG1 \\ 8DQ, U.K. E-mail: mark.everard@environment-agency.gov.uk
}

Key words: RHS, river habitat, sediment, Malewa, Gilgil, Karati

\begin{abstract}
Lake Naivasha is unique in the chain of East African Rift Valley lakes in being the only freshwater ecosystem in an otherwise soda/saline lake series. Catchment rivers have never previously been surveyed. Valley topography, precipitation patterns and geology create a diversity of river systems draining into Lake Naivasha. Semi-quantitative assessment using the River Habitat Survey technique demonstrates a diversity of habitats and erosion/sedimentation patterns, reflecting the tectonic origin of the area. The survey descriptions form a basis for identification of areas where efforts will need to be directed for physical and biological protection.
\end{abstract}

\section{Introduction}

Lake Naivasha $\left(0^{\circ} 45^{\prime} \mathrm{S}, 36^{\circ} 20^{\prime} \mathrm{E}\right.$; altitude $\left.1890 \mathrm{~m}\right)$ lies on the floor of Africa's Eastern Rift Valley and, at approximately $100 \mathrm{~km}^{2}$, is the second-largest freshwater lake in Kenya. It is one of a series of 23 major lakes in the East Rift Valley - eight in central Ethiopia, a further eight in Kenya and seven in Tanzania - spanning latitudes from approximately $7^{\circ} \mathrm{N}$ to $5^{\circ} \mathrm{S}$. The overall climate of the Eastern Rift Valley is semi-arid, with the exception of regions of central Ethiopia and central Kenya. All but four of these Eastern Rift Valley lakes are alkaline or saline. Lake Naivasha is unique within the central latitudes of the valley, and indeed within the Kenyan series of lakes (from north to south these are Turkana, Baringo, Bogoria, Nakuru, Elementeita, Naivasha, Magadi and Amboseli) in being fresh, with a mean conductivity of around $250 \mu \mathrm{S} \mathrm{cm}^{-1}$.

The surface inflows to the lake come via three main river systems - the Gilgil, the Malewa and the Karati - through a papyrus-dominated fringe in the northern part of the lake. The Malewa system is the largest with an estimated annual flow of 153 million $\mathrm{m}^{3}$, the Gilgil has an estimated average annual flow of 24 million $\mathrm{m}^{3}$, whereas the Karati only flows intermittently during the rainy season (Ase et al., 1986; Ase, 1987). The lake area fluctuates quite markedly and rapidly. For example, the heavy and prolonged precipitation caused by exceptional 'El Nino' climatic patterns between August 1997 and July 1998 resulted in a rise in lake level of $3 \mathrm{~m}$, pushing inland over a kilometre in the low-gradient north. The background to the lake is described by Harper (1984) and Harper et al. (1990, 1995).

A significant body of research has contributed to the designation of Lake Naivasha as Kenya's second Ramsar site (after Lake Nakuru) in 1995. Under the Ramsar designation, a lake management plan is required to co-ordinate the sustainable development of the lake (Ramsar, 1971). (The Ramsar Commission consider sustainable development to be consistent with 'wise use' as defined by Ramsar (1996)). Uniquely for a Ramsar site, the Kenyan government has delegated responsibility for management of the site to a non-statutory body; the Lake Naivasha Riparian Association (LNRA). The plan will be required to address conflicting pressures to resolve the issue of wise use. However, wider impacts on the lake deriving from the catchment have been largely overlooked. Everard (1998) notes that the conservation and sustainable 
management of aquatic ecosystems - whether rivers, wetlands or stillwaters - must be considered within the context of the living landscapes of which they are a part, and of the processes that form and sustain them. Considerations must also address not merely the flow of water but also of energy and sediment (Newson, 1992) as well as of pollutants, productivity products and biological inocula, channel roughness and micro-hydrodynamics within river channels. The services provided by wetland systems within catchments, which are widely overlooked in management decisions (Everard, 1997; Cairn, 1997), deliver substantial benefits to watercourses and water bodies, and to those that use and live near them, through the various hydrological, ecological, physical and social functions they perform (Dugan, 1990). Four-fifths of Kenya is arid or semi-arid and prone to drought (Mutiso, 1989), making more urgent wise use of water resources to support an increasing population, with its resultant pollution and economic development pressures (Orie, 1996).

This study represents the first documentation of catchment morphology and land use to support both a better understanding of impacts upon the lake, and further to inform wise use decisions.

\section{Methods}

Forty-four stretches of river throughout the Lake Naivasha catchment were surveyed during three sampling periods (August 1997, July 1998 and March/April 1999) using the River Habitat Survey (RHS) method. RHS is a method developed for England \& Wales for the Environment Agency, based on both map-derived and field survey data, which can be interpreted statistically (Raven et al., 1998). Site selection in the Naivasha catchment was initially map-based, with the intention of establishing a representative network, but final selection was constrained significantly by accessibility and safety considerations. RHS surveys were repeated at a minority of sites between years, and two sites were evaluated outside the catchment (streams in the adjacent Hell's Gate National Park) for comparative purposes. RHS sites are listed in Table 1, their location shown in Figure 1 and RHS data and site photographs are available on CD-ROM (Environment Agency \& Institute of Freshwater Ecology, 1999).

The survey was carried out in low flow conditions. Water depth and width were recorded and the

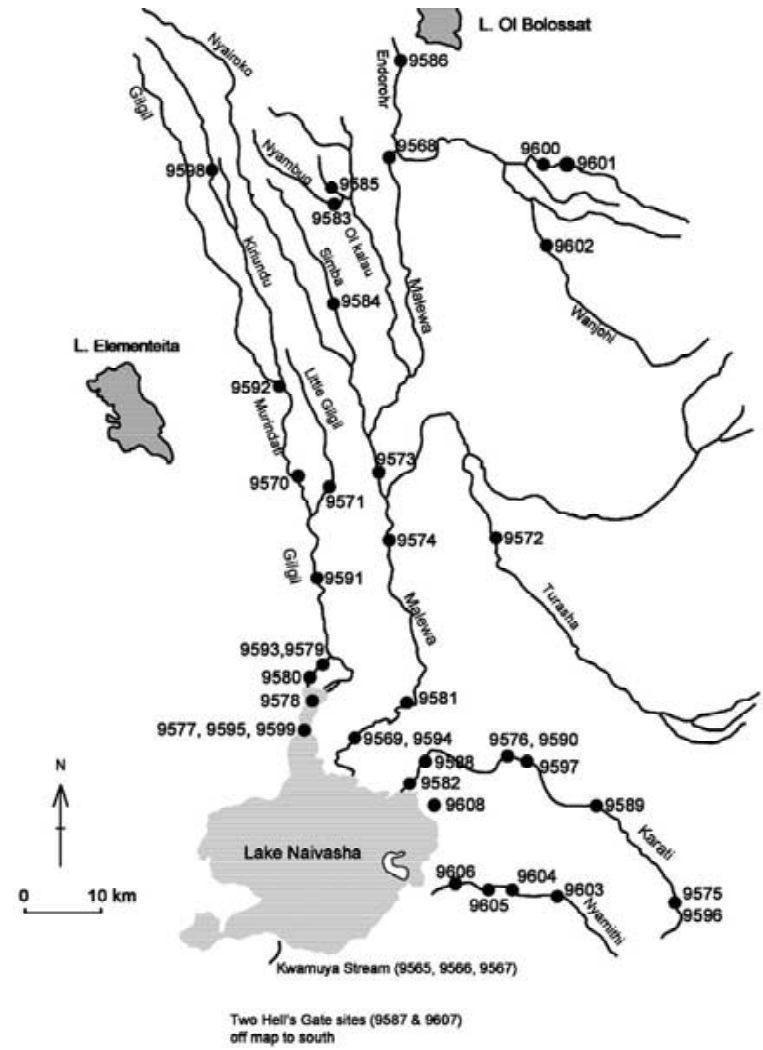

Figure 1. Lake Naivasha catchment showing the RHS sites.

percentage low/bankful flow calculated from:

$$
\begin{aligned}
& \text { \%low/bankful }= \\
& \frac{(\text { water depth } \times \text { water width })}{[(\text { bankful height }+ \text { water depth }) \times \text { bankful width }]} \times 100 .
\end{aligned}
$$

This calculation has no firm statistical basis since 'low flow' conditions recorded between field sampling periods may have varied, and the channel cross section calculation is simplified. However, the data are indicative of the proportion of low flow to high flow in river channels, and convey some concept of 'flashiness' .

As a surrogate of channel energy (the widespread occurrence of dry channels render flow type data unreliable) and sediment flow, the substrate distribution at $50 \mathrm{~m}$ transects within the RHS sites was recorded together with visible silt deposition features.

\section{Results}

The hydrology and climate of the Eastern Rift Valley, which has an unreliably low mean annual precipitation, is influenced by the topography of the escarp- 
Table 1. Features of RHS sites in the Naivasha catchment (site numbers in Figure 3)

\begin{tabular}{|c|c|c|c|c|}
\hline $\begin{array}{l}\text { RHS } \\
\text { site no. }\end{array}$ & RHS site (river system and site name) & Longitude/Latitude & $\begin{array}{l}\text { Approximate } \\
\text { altitude } \\
\text { (metres) }\end{array}$ & Date \\
\hline 9565 & KWAMUYA; BELOW ROAD & $36^{\circ} 19^{\prime} 37^{\prime \prime} \mathrm{E}, 00^{\circ} 49^{\prime} 23^{\prime \prime} \mathrm{S}$ & 1900 & $10 / 08 / 97$ \\
\hline 9566 & KWAMUYA; 0-500 m U/S ROAD & $36^{\circ} 19^{\prime} 23^{\prime \prime} \mathrm{E}, 00^{\circ} 49^{\prime} 47^{\prime \prime} \mathrm{S}$ & 1950 & $10 / 08 / 97$ \\
\hline 9567 & KWAMUYA; 500 m-1 km U/S ROAD & $36^{\circ} 18^{\prime} 58^{\prime \prime} \mathrm{E}, 00^{\circ} 50^{\prime} 21^{\prime \prime} \mathrm{S}$ & 2000 & $10 / 08 / 97$ \\
\hline 9568 & MALEWA; WANJOHI ROAD & $36^{\circ} 24^{\prime} 44^{\prime \prime} \mathrm{E}, 00^{\circ} 15^{\prime} 19^{\prime \prime} \mathrm{S}$ & 2290 & 06/08/97 \\
\hline 9569 & MALEWA; MARULA ESTATE & $36^{\circ} 22^{\prime} 03^{\prime \prime} \mathrm{E}, 00^{\circ} 40^{\prime} 47^{\prime \prime} \mathrm{S}$ & 1895 & $07 / 08 / 97$ \\
\hline 9570 & GILGIL; ARMY BARRACKS & $36^{\circ} 20^{\prime} 41^{\prime \prime} \mathrm{E}, 00^{\circ} 29^{\prime} 06^{\prime \prime} \mathrm{S}$ & 2000 & $16 / 08 / 97$ \\
\hline 9571 & LITTLE GILGIL; ARMY BARRACKS & $36^{\circ} 21^{\prime} 44^{\prime \prime} \mathrm{E}, 00^{\circ} 29^{\prime} 36^{\prime \prime} \mathrm{S}$ & 2000 & $16 / 08 / 97$ \\
\hline 9572 & TURASHA DAM & $36^{\circ} 30^{\prime} 00^{\prime \prime} \mathrm{E}, 00^{\circ} 34^{\prime} 42^{\prime \prime} \mathrm{S}$ & 2400 & $11 / 08 / 97$ \\
\hline 9573 & MALEWA; PUMP HOUSE & $36^{\circ} 23^{\prime} 41^{\prime \prime} \mathrm{E}, 00^{\circ} 29^{\prime} 36^{\prime \prime} \mathrm{S}$ & 2050 & $11 / 08 / 97$ \\
\hline 9574 & MALEWA; BELOW TURASHA & $36^{\circ} 24^{\prime} 05^{\prime \prime} \mathrm{E}, 00^{\circ} 31^{\prime} 03^{\prime \prime} \mathrm{S}$ & 2000 & $11 / 08 / 97$ \\
\hline 9575 & KARATI; KINANGOP PLATEAU & $36^{\circ} 35^{\prime} 16^{\prime \prime} \mathrm{E}, 00^{\circ} 47^{\prime} 11^{\prime \prime} \mathrm{S}$ & 2610 & $12 / 08 / 97$ \\
\hline 9576 & KARATI; GORGE & $36^{\circ} 28^{\prime} 42^{\prime \prime} \mathrm{E}, 00^{\circ} 41^{\prime} 11^{\prime \prime} \mathrm{S}$ & 2100 & $12 / 08 / 97$ \\
\hline 9577 & GILGIL; MARULA FLOODPLAIN & $36^{\circ} 20^{\prime} 55^{\prime \prime} \mathrm{E}, 00^{\circ} 40^{\prime} 32^{\prime \prime} \mathrm{S}$ & 1890 & $13 / 08 / 97$ \\
\hline 9578 & GILGIL; ANOSTOMOSED DELTA & $36^{\circ} 21^{\prime} 10^{\prime \prime} \mathrm{E}, 00^{\circ} 38^{\prime} 41^{\prime \prime} \mathrm{S}$ & 1890 & $27 / 08 / 97$ \\
\hline 9579 & GILGIL; U/S NORTH LAKE ROAD & $36^{\circ} 20^{\prime} 41^{\prime \prime} \mathrm{E}, 00^{\circ} 36^{\prime} 39^{\prime \prime} \mathrm{S}$ & 1900 & $17 / 08 / 97$ \\
\hline 9580 & GILGIL; D/S NORTH LAKE ROAD & $36^{\circ} 20^{\prime} 21^{\prime \prime} \mathrm{E}, 00^{\circ} 37^{\prime} 23^{\prime \prime} \mathrm{S}$ & 1895 & $17 / 08 / 97$ \\
\hline 9581 & MALEWA; KARI FARM & $36^{\circ} 25^{\prime} 13^{\prime \prime} \mathrm{E}, 00^{\circ} 38^{\prime} 26^{\prime \prime} \mathrm{S}$ & 1950 & $26 / 08 / 97$ \\
\hline 9582 & KARATI; NORTH SWAMP & $36^{\circ} 24^{\prime} 44^{\prime \prime} \mathrm{E}, 00^{\circ} 42^{\prime} 10^{\prime \prime} \mathrm{S}$ & 1890 & $21 / 08 / 97$ \\
\hline 9583 & NYAMBUG & $36^{\circ} 22^{\prime} 52^{\prime \prime} \mathrm{E}, 00^{\circ} 17^{\prime} 11^{\prime \prime} \mathrm{S}$ & 2350 & $25 / 07 / 98$ \\
\hline 9584 & SIMBA (OLEOLONDO) & $36^{\circ} 22^{\prime} 13^{\prime \prime} \mathrm{E}, 00^{\circ} 21^{\prime} 24^{\prime \prime} \mathrm{S}$ & 2290 & $25 / 07 / 98$ \\
\hline 9585 & OL KALOU & $36^{\circ} 22^{\prime} 47^{\prime \prime} \mathrm{E}, 00^{\circ} 16^{\prime} 28^{\prime \prime} \mathrm{S}$ & 2350 & $22 / 07 / 98$ \\
\hline 9586 & ENDOROHR; D/S OL BOLOSSAT & $36^{\circ} 25^{\prime} 03^{\prime \prime} \mathrm{E}, 00^{\circ} 12^{\prime} 44^{\prime \prime} \mathrm{S}$ & 2330 & $22 / 07 / 98$ \\
\hline 9587 & HELL'S GATE; LOWER GORGE & $36^{\circ} 19^{\prime} 13^{\prime \prime} \mathrm{E}, 00^{\circ} 52^{\prime} 47^{\prime \prime} \mathrm{S}$ & 2000 & $21 / 07 / 98$ \\
\hline 9588 & KARATI; MANERA & $36^{\circ} 25^{\prime} 23^{\prime \prime} \mathrm{E}, 00^{\circ} 41^{\prime} 45^{\prime \prime} \mathrm{S}$ & 1895 & $17 / 07 / 98$ \\
\hline 9589 & KARATI; RIFT WALL WATERFALL & $36^{\circ} 32^{\prime} 50^{\prime \prime} \mathrm{E}, 00^{\circ} 43^{\prime} 18^{\prime \prime} \mathrm{S}$ & 2500 & $17 / 07 / 98$ \\
\hline 9590 & KARATI; GORGE & $36^{\circ} 28^{\prime} 42^{\prime \prime} \mathrm{E}, 00^{\circ} 41^{\prime} 11^{\prime \prime} \mathrm{S}$ & 2100 & $17 / 07 / 98$ \\
\hline 9591 & GILGIL; U/S NAKURU ROAD & $36^{\circ} 21^{\prime} 44^{\prime \prime} \mathrm{E}, 00^{\circ} 32^{\prime} 55^{\prime \prime} \mathrm{S}$ & 1950 & $16 / 07 / 98$ \\
\hline 9592 & MORINDATI; U/S KAHUHO SCHOOL & $36^{\circ} 20^{\prime} 36^{\prime \prime} \mathrm{E}, 00^{\circ} 25^{\prime} 08^{\prime \prime} \mathrm{S}$ & 2200 & $19 / 07 / 98$ \\
\hline 9593 & GILGIL; U/S NORTH LAKE ROAD & $36^{\circ} 20^{\prime} 41^{\prime \prime} \mathrm{E}, 00^{\circ} 36^{\prime} 39^{\prime \prime} \mathrm{S}$ & 1900 & $15 / 07 / 98$ \\
\hline 9594 & MALEWA; MARULA & $36^{\circ} 22^{\prime} 03^{\prime \prime} \mathrm{E}, 00^{\circ} 40^{\prime} 47^{\prime \prime} \mathrm{S}$ & 1895 & $20 / 07 / 98$ \\
\hline 9595 & GILGIL; MARULA FLOODPLAIN & $36^{\circ} 20^{\prime} 55^{\prime \prime} \mathrm{E}, 00^{\circ} 40^{\prime} 32^{\prime \prime} \mathrm{S}$ & 1890 & $20 / 07 / 98$ \\
\hline 9596 & KARATI; KINANGOP PLATEAU & $36^{\circ} 35^{\prime} 16^{\prime \prime} \mathrm{E}, 00^{\circ} 47^{\prime} 11^{\prime \prime} \mathrm{S}$ & 2610 & $25 / 03 / 99$ \\
\hline 9597 & KARATI; CASCADE U/S GORGE & $36^{\circ} 29^{\prime} 16^{\prime \prime} \mathrm{E}, 00^{\circ} 41^{\prime} 02^{\prime \prime} \mathrm{S}$ & 2130 & $30 / 03 / 99$ \\
\hline 9598 & KIRIUNDU; DONDORI ROAD & $36^{\circ} 17^{\prime} 41^{\prime \prime} \mathrm{E}, 00^{\circ} 14^{\prime} 50^{\prime \prime} \mathrm{S}$ & 2560 & $05 / 04 / 99$ \\
\hline 9599 & GILGIL; MARULA FLOODPLAIN & $36^{\circ} 20^{\prime} 55^{\prime \prime} \mathrm{E}, 00^{\circ} 40^{\prime} 32^{\prime \prime} \mathrm{S}$ & 1890 & $31 / 03 / 99$ \\
\hline 9600 & MALEWA; 0-500m U/S KIRIMA & $36^{\circ} 30^{\prime} 34^{\prime \prime} \mathrm{E}, 00^{\circ} 13^{\prime} 52^{\prime \prime} \mathrm{S}$ & 2500 & $27 / 03 / 99$ \\
\hline 9601 & MALEWA; 500m-1km U/S KIRIMA & $36^{\circ} 30^{\prime} 54^{\prime \prime} \mathrm{E}, 00^{\circ} 14^{\prime} 02^{\prime \prime} \mathrm{S}$ & 2700 & $27 / 03 / 99$ \\
\hline 9602 & WANJOHI; WANJOHI & $36^{\circ} 29^{\prime} 50^{\prime \prime} \mathrm{E}, 00^{\circ} 18^{\prime} 15^{\prime \prime} \mathrm{S}$ & 2390 & $27 / 03 / 99$ \\
\hline 9603 & NYAMITHI; D/S NEW ROAD & $36^{\circ} 30^{\prime} 39^{\prime \prime} \mathrm{E}, 00^{\circ} 47^{\prime} 02^{\prime \prime} \mathrm{S}$ & 2295 & $25 / 03 / 99$ \\
\hline 9604 & $\begin{array}{l}\text { NYAMITHI; GORGE ON SLOPE U/S } \\
\text { OLD ROAD }\end{array}$ & $36^{\circ} 28^{\prime} 13^{\prime \prime} \mathrm{E}, 00^{\circ} 46^{\prime} 42^{\prime \prime} \mathrm{S}$ & 2060 & 26/03/99 \\
\hline 9605 & $\begin{array}{l}\text { NYAMITHI; GORGE IN FLATLAND } \\
\text { U/S OLD ROAD }\end{array}$ & $36^{\circ} 27^{\prime} 58^{\prime \prime} \mathrm{E}, 00^{\circ} 46^{\prime} 42^{\prime \prime} \mathrm{S}$ & 2000 & 26/03/99 \\
\hline 9606 & NYAMITHI; SHAMBA & $36^{\circ} 27^{\prime} 00^{\prime \prime} \mathrm{E}, 00^{\circ} 46^{\prime} 18^{\prime \prime} \mathrm{S}$ & 1990 & 04/04/99 \\
\hline 9607 & HELL'S GATE; CENTRAL TOWER & $36^{\circ} 20^{\prime} 55^{\prime \prime} \mathrm{E}, 00^{\circ} 53^{\prime} 16^{\prime \prime} \mathrm{S}$ & 2000 & $04 / 04 / 99$ \\
\hline 9608 & $\begin{array}{l}\text { PELICAN FARM; CONSTRUCTED } \\
\text { WETLAND }\end{array}$ & $36^{\circ} 25^{\prime} 42^{\prime \prime} \mathrm{E}, 00^{\circ} 42^{\prime} 24^{\prime \prime} \mathrm{S}$ & 1890 & $06 / 04 / 99$ \\
\hline
\end{tabular}


ments. Consequently, the majority of the series of lakes are soda or alkaline due to the concentration of solutes through evapotranspiration. By contrast, Lake Naivasha is a freshwater body, apparently due to topography and orographic processes across its catchment. Lake Naivasha lies between the 'walls' of the Eastern Rift Valley: the Mau Escarpment rising to 3048 metres to the west and the Nyandarua Mountains rising to 4000 metres to the east. These ridges are among the highest ranges in the central part of the Eastern Rift Valley, and are likely to have sufficient elevation to cause climatic conditions that result in greater rainfall relative to other major lake catchments. A schematic diagram of the orographic and hydrographic regime of the catchment is provided in Figure 2 (reliable rainfall data across the catchment are not available). The presence of a number of the larger perennial rivers of the Malewa and Gilgil systems to the north and west, relative to only several temporary rivers to the south and west and few blind streams running from the Mau Escarpment to the west, provide evidence substantiating this model. The persistence of the Malewa and Gilgil systems may also suggest the existence of rainfall percolation into perched groundwater tables that feed the river system during dry periods.

Channel gradients of the major river systems are shown in Figures 3 and 4 and Table 2. Changes in channel dimensions with passage downstream are shown for the three main rivers and also for the Nyamithi (a temporary system rising on the Kinangop plateau) and the Kwamuya Stream (representative of the ephemeral dry streams from the dry southern slopes of the lakeshore) are summarised in Figures 5 and 6. As a surrogate of channel energy (the widespread occurrence of dry channels render flow type data unreliable) and sediment flow, Figures 7 and 8 shows the substrate distribution at $50 \mathrm{~m}$ transects within the RHS sites, respectively, in the Malewa, Gilgil, Karati and Nyamithi river systems. Silt deposition features recorded in the Malewa, Gilgil and Karati river systems are presented, respectively, in Figure 9 (no discrete depositional features were present in RHS sites on the Nyamithi system).

\section{The Malewa river system}

The Malewa river system is significantly more dendritic than other systems in the catchment, with headwaters and tributaries rising at a range of altitudes. The headwater of the main channel of the Malewa River rises in the Nyandarua Mountains at $3700 \mathrm{~m}$ altitude,
Table 2. Stream orders and topography in the Naivasha catchment

\begin{tabular}{llll}
\hline $\begin{array}{l}\text { River } \\
\text { system }\end{array}$ & $\begin{array}{l}\text { Stream } \\
\text { order }\end{array}$ & $\begin{array}{l}\text { Maximum } \\
\text { horizontal } \\
\text { channel } \\
\text { length }(\mathrm{km})\end{array}$ & $\begin{array}{l}\text { Maximum } \\
\text { height } \\
\text { drop (m) }\end{array}$ \\
\hline Malewa & $6 / 7$ & 109 & 1921 \\
Gilgil & 3 & 60 & 873 \\
Karati & 1 & 30 & 760 \\
Nyamithi & 1 & 13 & 740 \\
Kwamuya & 1 & 2 & 110 \\
\hline
\end{tabular}

and several small rivers feed into the Wanjohi system from the slopes of the Nyandaruas. The Endorohr system arises as a westerly outflow from Lake Ol Bolossat when lake levels are high (as observed, for example, following the 'El Nino' rains in 1997), at an altitude of $2400 \mathrm{~m}$. The Endorohr here has the characteristics of a grassy swale, interpersed with Cyperus-dominated pools, a temporary river in a moist and cool upland setting. The Turasha sub-catchment, arising to the East of the Kipipiri mountain, is dammed to provide fresh water for the town of Nakuru, creating a fresh stillwater habitat at approximately $3000 \mathrm{~m}$ altitude. This feeds into an otherwise high-energy river system. Both the Malewa/Wanjohi and the Turasha sub-catchments fall rapidly from source to the altitude at which the Endorohr, Ol Kalou, Nyambug and Simba rivers rise, falling at lower gradient to approximately $40 \mathrm{~km}$ north of Lake Navasha where they once again fall at higher gradient cutting through the plateau north of the lake (up to $30 \mathrm{~km}$ distance from the river mouth).

Water width/depth data demonstrate the perennial nature of all rivers in the Malewa system, with channel sizes which tend to increase downstream with all rivers remaining relatively shallow. Channel substrates, reflective of stream energy, reflect channel topography with the steep Ol Kolau and Nyambug systems being bedrock-dominated and the Simba river being dominated by boulders. Conversely, the relatively low-gradient Endorohr and the dammed (at the RHS site) Turasha tributaries have a sediment of fines (combining soil, silt, clay and peat). Below the Turasha confluence, the substrate of the Malewa system grades from gravel/pebble to fines at the low-energy river mouth. Silt deposition features generally reflect this energy gradient, although side-bars present at $\mathrm{Ol}$ Kolau and Nyambug river sites suggest high sediment 


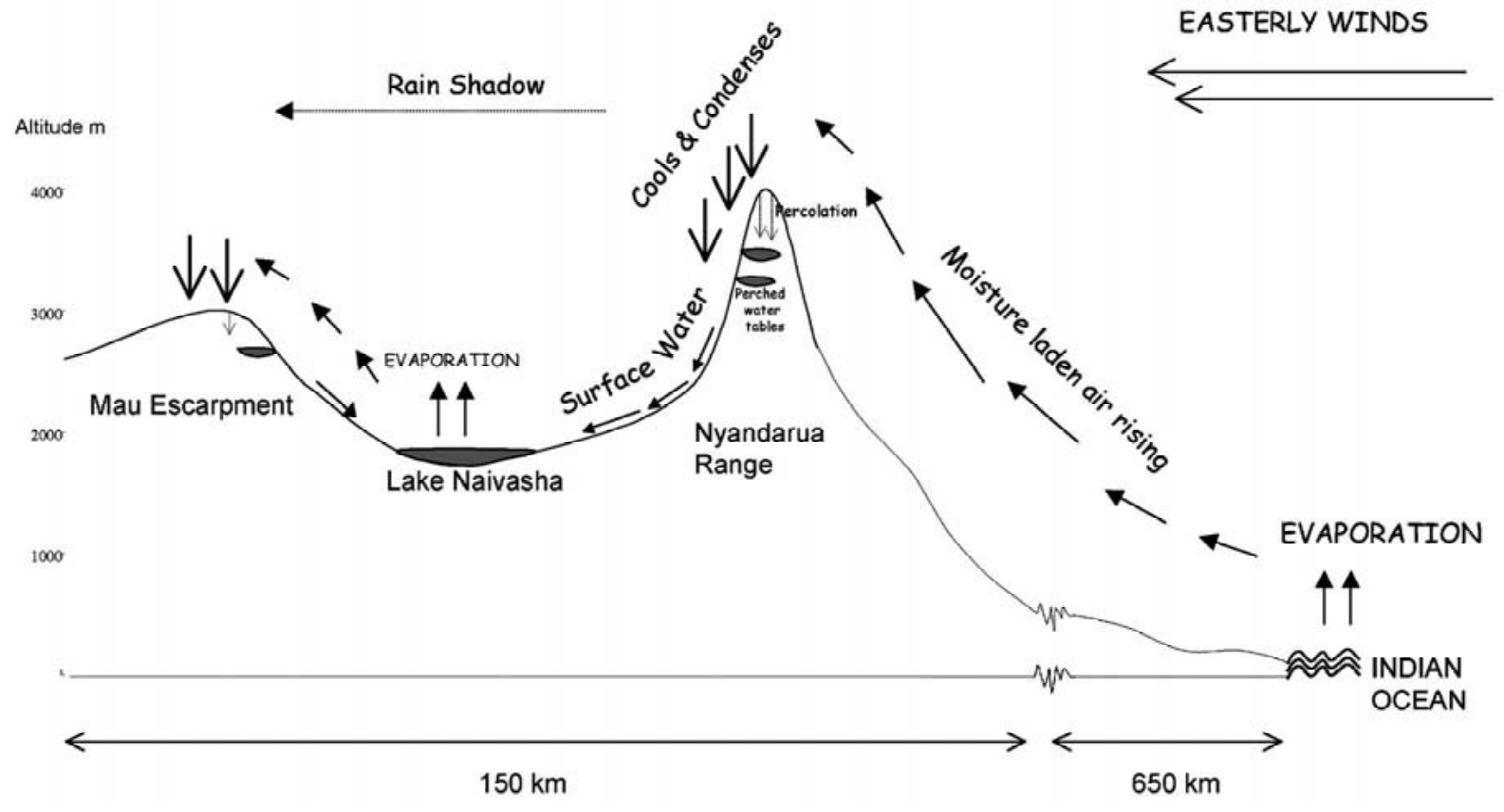

Figure 2. Profile and orographic model of the Eastern Rift Valley through the Naivasha catchment.

Altitude (m)

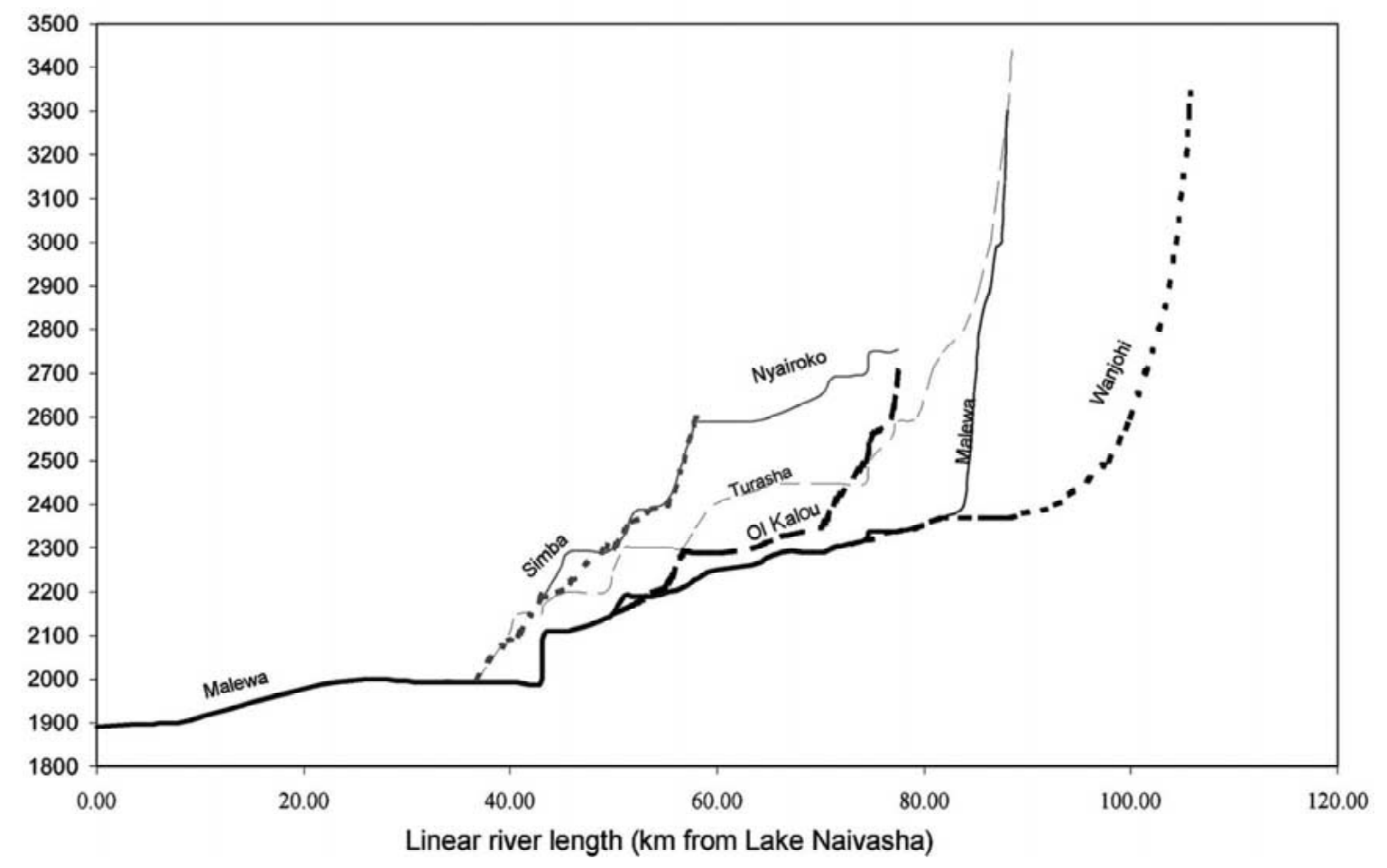

Figure 3. Channel topography of the Malewa river and its major tributaries. 


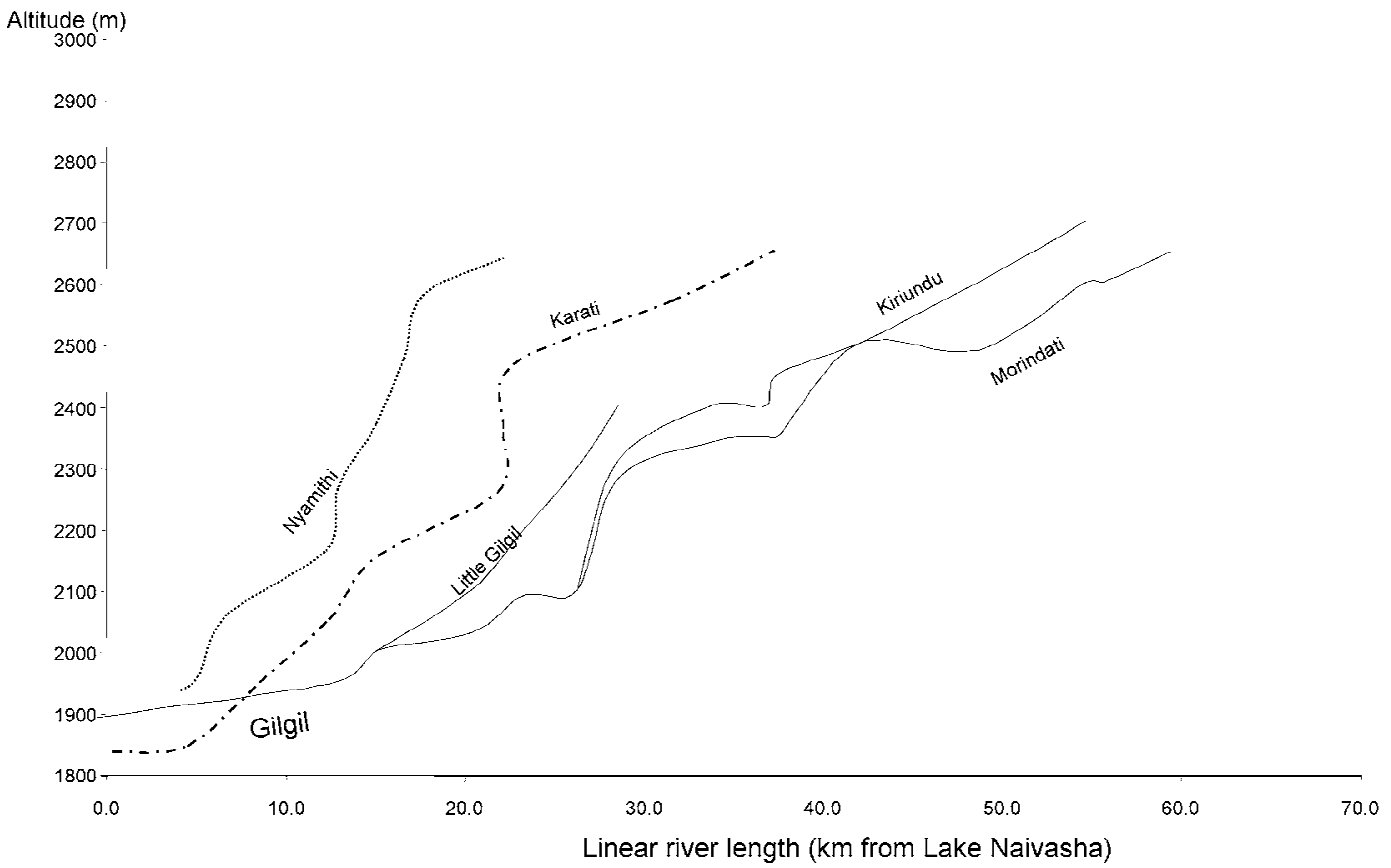

Figure 4. Channel topography of the Gilgil river and its tributaries, and the Karati and Nyamithi rivers.

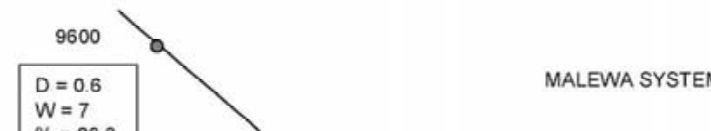


KARATI

\begin{tabular}{|c|c|c|c|c|}
\hline $\begin{array}{l}D=0.65 \\
W=2.5 \\
\%=3.6\end{array}$ & $\begin{array}{l}D=0 \\
W=8 \\
\%=0\end{array}$ & $\begin{array}{l}D=0.1 \\
W=1 \\
\%=0.8\end{array}$ & $\begin{array}{l}D=0 \\
W=3 \\
\%=5.6\end{array}$ & $\begin{array}{l}D=0 \\
W=2.5 \\
\%=0\end{array}$ \\
\hline 9596 & 9597 & 9576 & 9588 & 9582 \\
\hline
\end{tabular}

NYAMITHI

\begin{tabular}{|c|c|c|c|}
\hline $\begin{array}{l}D=0.65 \\
W=2.5 \\
\%=3.6\end{array}$ & $\begin{array}{l}D=0 \\
W=6 \\
\%=0\end{array}$ & $\begin{array}{l}D=0 \\
W=0.6 \\
\%=0\end{array}$ & $\begin{array}{l}D=0 \\
W=3 \\
\%=0\end{array}$ \\
\hline 9603 & 9604 & 9605 & 9606 \\
\hline
\end{tabular}

KWAMUYA

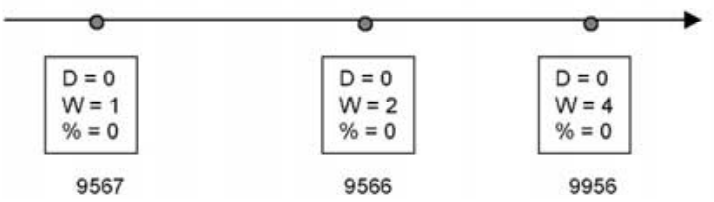

$D=$ Water depth (low flow)

$W=$ Water width (low flow)

$\%=$ Low/Bankfull flow (see text)

Figure 6. Channel dimensions (as explained in text) of the Karati, Nyamithi and Kwamuya river systems.

inputs upstream. Point bars present at the Turasha dam and down river at both the KARI and Marula sites suggest significant channel activity in these reaches. The Malewa discharges directly into Lake Naivasha with no dissipation into papyrus swamp as occurred in the 1970s (Gaudet, 1977). In August 1997, distinct sediment-laden plumes of Malewa river water were visible up to an estimated $500 \mathrm{~m}$ into the lake.

Scrub and rough pasture were the most extensive forms of riparian land use throughout the Malewa catchment although, in some areas, tillage of the land for subsistence agriculture and cash crops was evident right up to the river banks. There was also evidence of extensive erosion and poaching of the river banks in some river stretches, apparently as a result of over-grazing. Artificial features were otherwise not widespread, the most significant exception being the Turasha dam.

\section{The Gilgil system}

The Gilgil system is third-order with three headwaters: the Morindati (rising at $2700 \mathrm{~m}$ ), the Kiriundu $(2710 \mathrm{~m})$ and the Little Gilgil $(2400 \mathrm{~m})$. The upland river sections of all three Gilgil tributaries have a rel- atively flat topography before cutting into the plateau approximately $40-50 \mathrm{~km}$ north of Lake Naivasha to the flatlands approaching the lake.

Water width/depth data indicate shallow perennial river systems, generally increasing in width downstream. Percentage of low flow/bankful appear relatively higher than the Malewa system indicating stronger base flows; there is a perennial volcanic groundwater input at Chamuka Spring near the settlement of Chokeraria. In contrast to other river systems in the catchment, the Gilgil opens into a broad floodplain immediately north of the lake, with an anostomosed section of river, now heavily modified for direct irrigation.

Bedrock channel substrate is predominant at the steep section of the Morindati River upstream of Kahuho school, and also occurs in regions of channel scour at Gilgil Weir. However, the river is otherwise gravel/pebble grading to fines reflecting topography and energy. Silt deposition features are not widespread in the river system, although they are common at the Army Barracks (Gilgil Town), Nakuru Road and Maasai Ridge sites. This is reflective of both overgraz- 


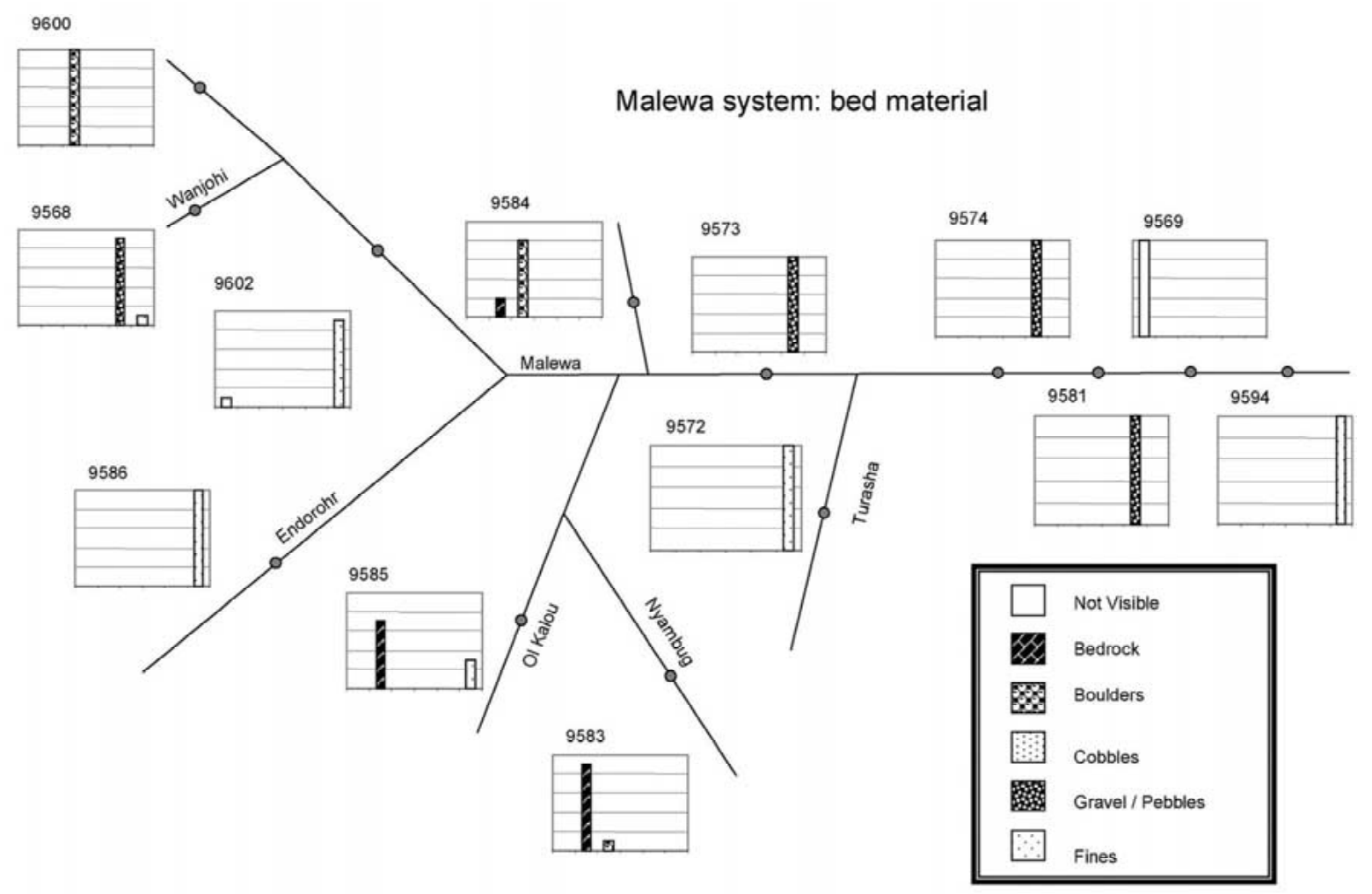

Figure 7. Substrates at ten survey transects within RHS sites on the Malewa River system.

ing/poaching and channel activity (as indicated by side bars) in this higher-gradient reach of the river.

Despite perennial flows, the broad Gilgil floodplain north of Lake Naivasha disperses river energy, and the low gradient upstream of this results in fall out of sediments (and associated substances) well short of the lake. Owing to both of these features, river energy is dispersed short of the lake, and the Gilgil River consequently lacks a clear mouth.

Scrub and rough pasture are the predominant riparian landscape types in the Gilgil catchment, although some tilled land is present near the river banks. Erosion through overgrazing and poaching, by both stock and game, are evident lower in the catchment.

\section{The Karati system}

The Karati is a relatively shorter, steeper system that has no significant tributaries and is purely firstorder. The headwater rises at an altitude of $2600 \mathrm{~m}$ (approximately the same altitude range as the Gilgil headwaters and many of those of the Malewa) on the Kinangop plateau, but cascades steeply from the Rift
Valley edge towards the flatter lands bordering the eastern lake shore.

Depth/width data indicate a predominantly dry river. Despite low \% low flow/bankful, data suggest terracing, indicative of differing flow regimes over longer timescales. The flatter gradients on the Kinangop plateau result in a mid-energy gravel/pebble/cobble channel substrate, through high river energy as the Karati falls steeply through the gorge section resulting in a predominantly boulder or bedrock substrate. It rarely flows in the flatter topography near the lake itself, and the channel substrates at sites Manera and the North Swamp overwhelmingly comprise fines. Some silt deposition is evident at Kinangop, reflecting agricultural activity. Small silt deposits are also present at the Gorge site where marginal slacks in the gorge permit deposition of high sediment loads arising from grazing/poaching and riverside tillage of land. Silt deposition is also evident at the North Swamp site.

Rough pasture and scrub are common riparian landscapes throughout the catchment, however subsistence and cash crop agriculture are extensive on the Kinangop Plateau and immediately above the Karati 


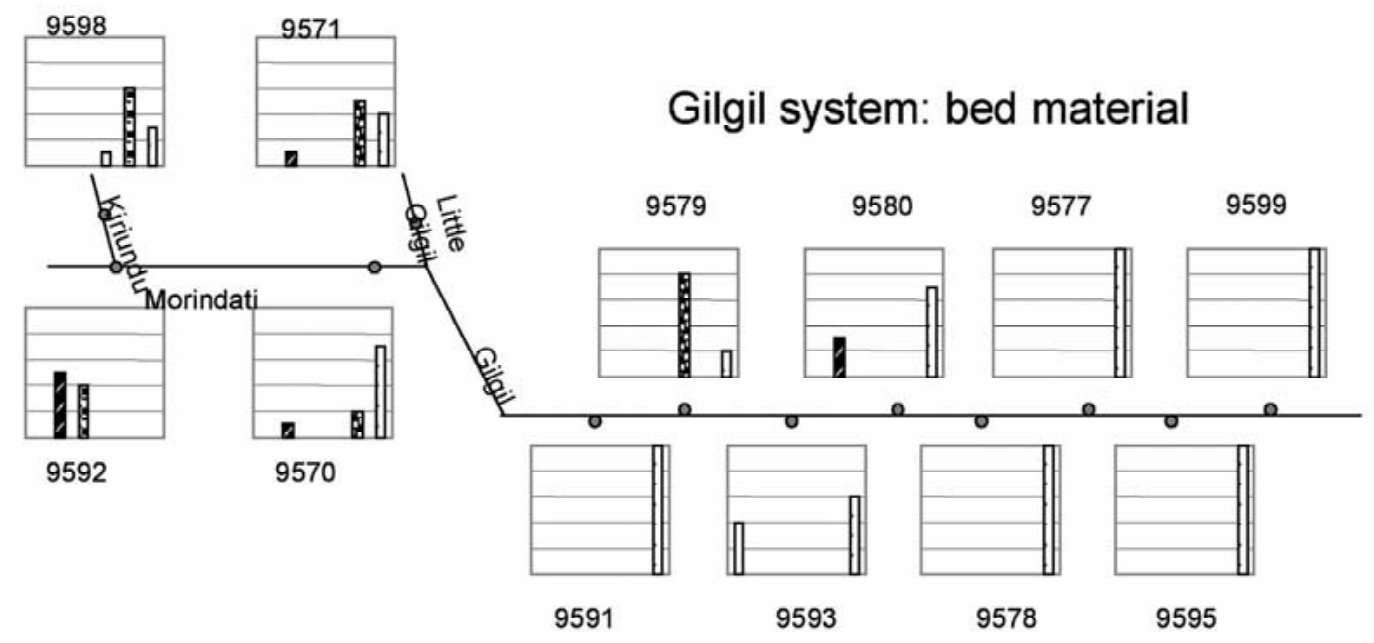

Karati system: bed material
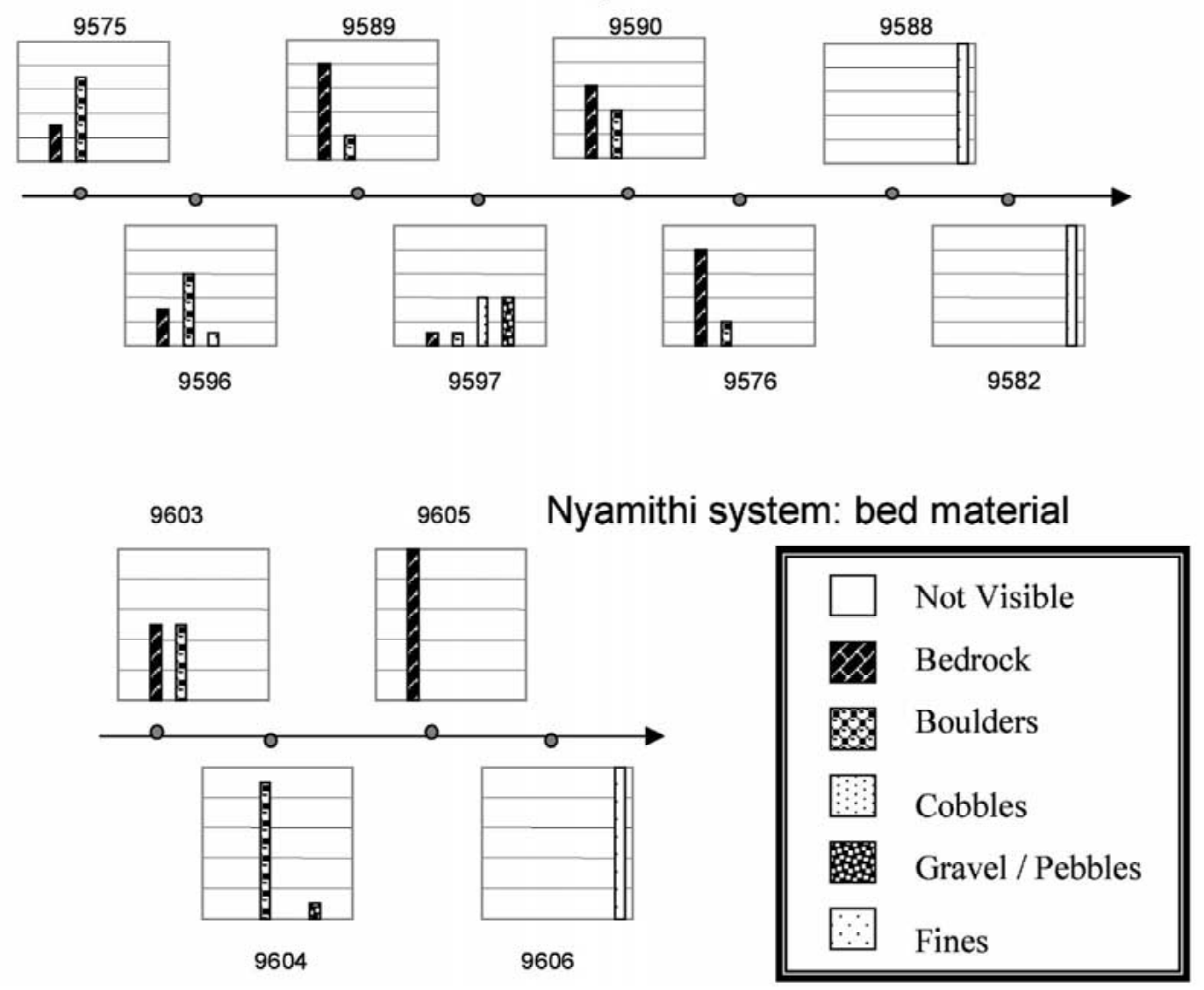

Figure 8. Substrates at ten survey transects within RHS sites on the Gilgil, Karati and Nyamithi river systems. 

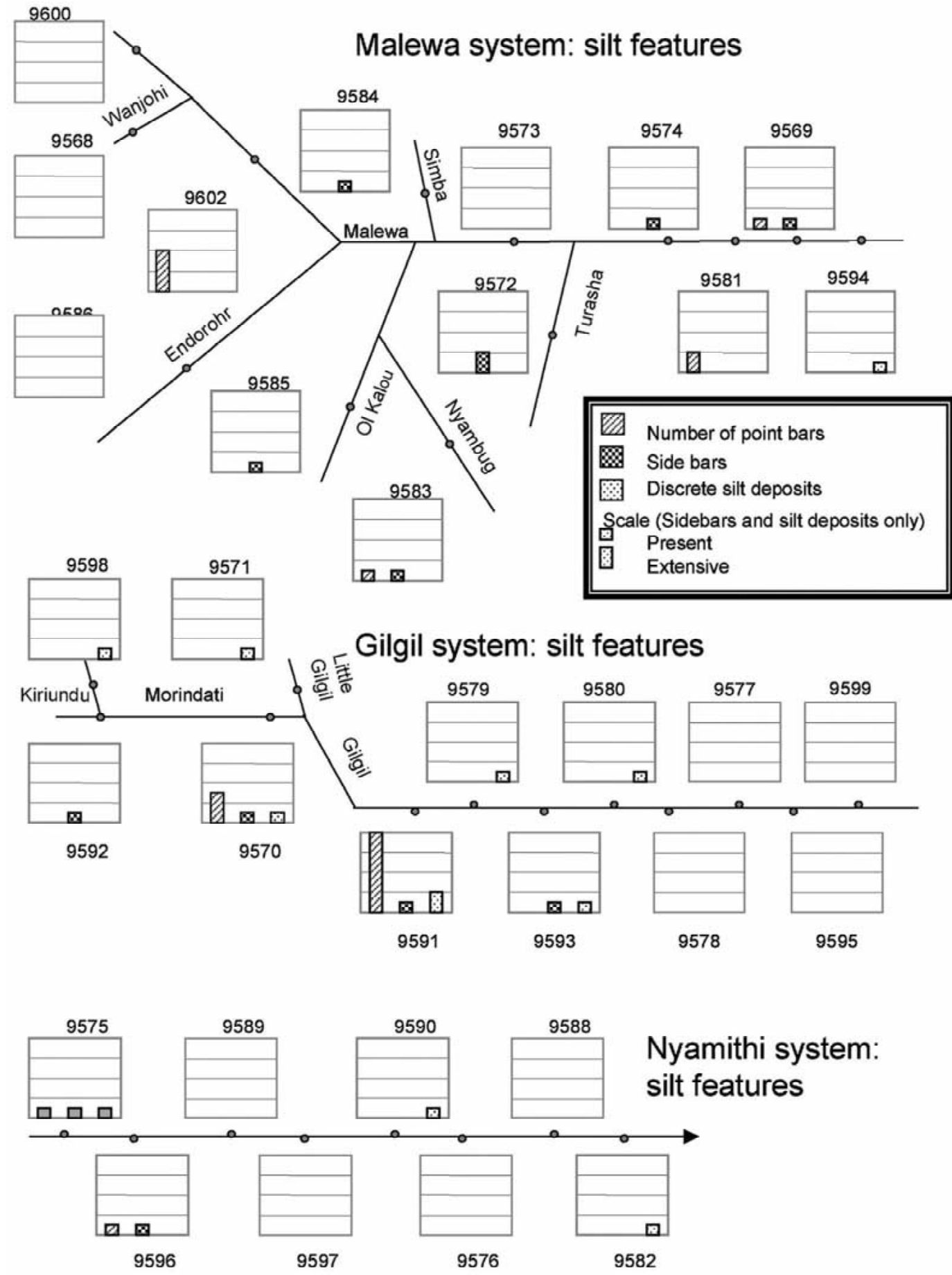

Figure 9. Silt features at ten survey transects within RHS sites on the Malewa, Gilgil and Karati river systems. 
gorge. The Karati is however virtually 'blind', dispersing into the North Swamp through various distributary channels with no clear opening to the lake. Sediment flows from upstream erosion appear to contribute significantly to a delta-forming process.

\section{The Nyamithi system}

The Nyamithi is a shorter and steeper first order system even than the Karati. Despite the channel becoming indistinct some $4 \mathrm{~km}$ short of the lake, there is overland flow over farmland to the lake shore during heavy rainfall events. The Nyamithi is predominantly dry with a small channel width, but the bedrock/boulder substrate in all but the lowland (Shamba) site indicate substantial river energy during periods of high flow. Fines eroded from these events contribute to the silt/mud bed of the increasingly indistinct river channel at the Shamba site.

There is evidence from the terraced valleys and deeply incised/engorged channels through most of the river length that the Nyamithi had significantly greater flashing volumes over longer geological timescales than at present. These appear to have deposited substantial amounts of silt into the lake, forming a delta which current flow volumes are now incapable of penetrating.

\section{The Kwamuya stream}

The Kwamuya has been surveyed from the source to the blind end as an example of one of the several temporary rivers running from the southern slopes of the catchment. It is a steep, short first-order stream which stops some $100 \mathrm{~m}$ short of the lake edge. The land between the end of the river channel and the lake shore is cultivated, and the lakeside papyrus fringe is entire.

The river is dry for most of the year, reportedly running only for a few days a year following periods of heavy rainfall. Channel width increases downstream. Bedrock and boulders are predominant throughout most of the river system, although heavy overgrazing results in substantial erosion contributing to the silt deposits at the blind ending of the river. The delta-forming processes postulated for the Nyamithi system may also contribute to lowland silt deposits at a significantly smaller scale in the Kwamuya system.
Erosion, depostion and sedimentation in the river systems

The data demonstrate a largely predictable pattern predominantly of erosion (indicated by bedrock, boulder and cobble channel substrates, and gorged or deep $\mathrm{V}$ valley forms) in the upper catchment, and the deposition of sediments (channel substrate composed of fines, with side bars and point bars) in the lower catchment. In addition to this relationship between topography/erosion and bed type/depositional features, Tarras-Wahlberg et al. (2002) also found a distinct relationship between topography/channel pattern and the maturity, shape and size of riverine sediment particles.

Overlaid upon this pattern are poaching of river banks and erosion, sometimes severe, recorded throughout the catchment. High sediments loads from the Malewa catchment were responsible for the visible plume extending from the mouth of the Malewa river into the lake.

It is possible, based on findings of this initial study of the Naivasha catchment, to make a preliminary classification of the zones within the catchment, which has potential value in setting a geographic context for the delivery of sustainable development within the catchment (Figure 10).

\section{Discussion}

The initial purpose of the Naivasha catchment research programme was to establish a datum against which to assess future change. This is also potentially valuable in determining 'hotspots' of biological interest and problems, and supporting land use decisions. Any threat to the hydrological regime of the Naivasha catchment could have potentially substantial consequences for the lake and river ecosystems, given the apparent fine balance of inputs and outputs contributing to the unique freshwater character of Lake Naivasha.

Erosion and loss of topsoil are a significant problem worldwide and the magnitude of the problem is amplified by both the thin erosive volcanic soils and the increasing intensity and land use. Poorly-advised land use practices such as tillage to the banktop and unrestricted stock access are commonplace, and may contribute to increasing erosion. Unsympathetic riparian land management leading to vegetation loss and erosion also results in reductions in infiltration, further 


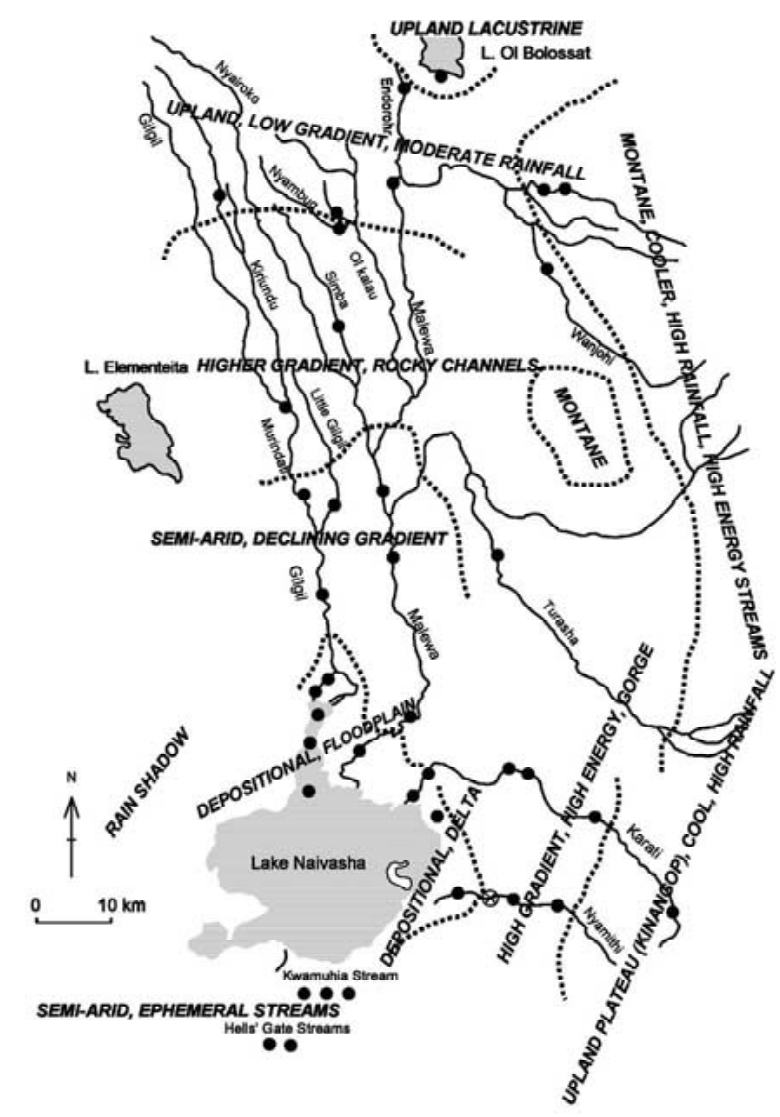

Figure 10. Preliminary classification of the Lake Naivasha catchment.

accelerating sheet and gully erosion by increasing runoff, and reducing the structure of soils as well as their capacity to retain moisture.

The former influence of the North Swamp and the fringing papyrus would have played an extremely important role in immobilising the sediment load from the river systems (Gaudet, 1979). The visible evidence of sediment plumes indicate the significance of the loss of the papyrus to the lake. Land management and erosion control in the catchment therefore appear to be a significant issue potentially deteriorating the quality of Lake Naivasha.

The proposal to dam the main stem of the River Malewa to supply growing demands for fresh water at Nakuru Town is also of concern. Hydrological, geomorphological, chemical and ecological consequences in both the Naivasha and Nakuru catchments, together with the social and economic needs sustained by these ecosystem services, need to be considered in detail - informed by sound science - to evaluate the sustainability of any proposal to impound rivers within the catchment. These theoretical problems are more than just speculation, based on lessons being learned elsewhere in the Rift Valley and across the tropics.

Adverse development in catchments, often remote from the receiving water body itself, is widely recognised as a major contributor to degradation in lake quality. However, recognition of river conservation in the developing world as a means for stemming ecological damage, and consequent adverse social and economic harm, is a more recent phenomenon (Barel et al., 1985). Sustainable development must be addressed at catchment scale if it is to be effective, taking an integrated approach to protection of both lake and catchment ecosystems and the livelihoods they sustain.

To protect the unique characteristics of Lake Naivasha, and the social and economic development that depends upon it, considerable further study of the river catchments is required. An improved understanding of interactions between the lake and influent rivers, and changing patterns of land use and habitation across the catchment, are essential to support sustainable policies. Rivers also integrate the influences of changing land use within the catchment (Newson, 1992) and so river monitoring can prove a cost-effective method for monitoring whether sustainable catchment management is being achieved (Ormerod \& Juttner, 1998). Once appropriate indicators are identified, routine river monitoring will become a priority to determine, and develop strategies for managing, impacts on Lake Naivasha deriving from its catchment.

\section{Acknowledgements}

This study formed part of the work of the University of Leicester research project at Lake Naivasha, which since 1987 has been authorised by the Office of the President, Government of Kenya under research permit to Dr D. M. Harper no. OP 13/001/12C 46. The project was funded by the Earthwatch Institute, Boston USA and Oxford, England. The data collection would not have been possible without the assistance of numerous Earthwatch volunteers or the facilities at the erstwhile Elsamere Conservation Centre. Our sincere thanks go to the numerous colleagues in Kenya for logistical help, in particular Jill and Angus Simpson and Velia Carn, and Chris Campbell Clause. The authors benefited from dialogue with R. Stadtmuller. Peter Scarlett and Hugh Dawson were extremely helpful in managing input of RHS data to the CD- 
ROM/central RHS database, and extracting relevant pieces of data for subsequent analysis.

\section{References}

Ase, L.-E., 1987. A note on the water budget of Lake Naivasha, Kenya. Geografiska Annaler: 69: 415-429.

Ase, L.-E., K. Sernbo \& P. Syren, 1986. Studies of Lake Naivasha, Kenya and its drainage area. Stockholms Universitet Naturgeografiska Institutionen Stockholm. 63: 77 pp.

Barel, C. N. D., R. Dorit \& D. H. Greenwood, 1985. Destruction of fisheries in Africa's lakes. Nature 315: 19-20.

Cairn, J. Jr., 1997. Defining goals and conditions for a sustainable world. Environmental Health Perspectives 105: 1164-1170.

Denny, P. (ed.), 1985. The Ecology and Mangement of African Wetland Vegetation. Dr W. Junk Publishers, Dordrecht.

Dugan, P. J., 1990. Wetland Conservation: A Review of Current Issues and Required Action. IUCN, Gland, Switzerland 96 pp.

Environment Agency \& Institute of Freshwater Ecology, 1999. River Habitat Survey Database 1999 (CD-ROM). Environment Agency, Rio House, Aztec West, Bristol, U.K.

Everard, M., 1997. Development of a British wetland strategy. Aquat. Conserv. 7: 223-238.

Everard, M., 1998. Application of The Natural Step to water management. J. Inst. Environ. Sci. 7: 10-13.

Gaudet, J. J., 1979. Seasonal changes in the nutrients in a tropical swamp: North Swamp, Lake Naivasha. J. Ecol. 67: 953-981.

Harper, D. M., 1984. Recent changes in the ecology of Lake Naivasha, Kenya. Verh. int. Ver. Limnol. 22: 1193-1197.

Harper, D. M., C. Adams \& K. Mavuti, 1995. The aquatic plant communities of the Lake Naivasha wetland, Kenya: pattern, dynamics and conservation. Wetlands Ecology and Management 3: $111-123$.
Harper, D. M., K. M. Mavuti \& S. M. Muchiri, 1990. Ecology and management of Lake Naivasha, Kenya in relation to climate change, alien species introductions and agricultural development. Environ. Conserv. 17: 328-336.

Mutiso, G. C., 1989. Managing Kenya's Arid and Semi-Arid Areas. In Kiriro, A. \& C. Juma (eds), Gaining Ground: Institutional Innovations in Land Use Management in Kenya. Nairobi, African Centre for Technology Studies: $76 \mathrm{pp}$.

Newson, M., 1992. Land, Water and Development: River Basin Systems and Their Sustainable Management. Routledge, London.

Orie, K. K., 1996. Proposed amendment to Kenya's water legislation: some missing sustainable water resources management principles. Wat. Res. Dev. 12: 79-88.

O'Riordan, T., 1993. The politics of sustainability. In Turner, K. (ed.), Sustainable Environmental Economics and Management: Principles and Practice. Belhaven, London: 37-69.

Ormerod, S. \& I. Juttner, 1998. Catchment sustainability and river biodiversity in Asia: a case study from Nepal. In Harper, D. M. \& A. Brown (eds), John Wiley and Sons Ltd: 187-207.

Ramsar, 1971. Convention on Wetlands of International Importance Especially as Waterfowl Habitat. 2/2/71, Ramsar, Iran.

Ramsar, 1996. The Ramsar 25th Anniversary Statement. Resolution VI.14, 6th Meeting of the Conference of the Contracting Parties, Brisbane, March 1996.

Raven, P. J., N. T. H. Holmes, F. H. Dawson, P. J. A. Fox, M. Everard, I. R. Fozzard \& K. J. Rouen, 1998. River Habitat Quality: The Physical Character of Rivers and Streams in the U.K. and the Isle of Man. Environment Agency, Bristol.

Tarras-Wahlberg, H., M. Everard \& D. M. Harper, 2002. Geochemical and physical characteristics of river and lake sediments at Naivasha, Kenya. Hydrobiologia 488 (Dev. Hydrobiol. 168): 27-41. 